\title{
Study of Weed Prevalence On Rape Crop To Planting Different Time
}

\author{
Author: Azzaya.T*, Amarsaikhan.J, Munkhtsetseg.D, \\ Otgonsuren.M
}

Affiliation: Institute of plant protection

E-mail:*Azzayatumenkhuu@gmail.com

\section{DOI: 10.26821/IJSHRE.9.1.2021.9130}

\begin{abstract}
The main purpose of this study was to determine of the weed species and its distribution in the rapeseed fields with different soil cultivation (by mechanic and chemical) and planting time were different (from 13 Apr to 15 May) in fields of "Gatsuurt" CoLTD in the Tsagaannuur soum of Selenge province, Mongolia. A total weed species of the experimental fields was determined by methods of E.I.Liberschtaine and A. Tulikov. Used of herbicides, which are Tornoda500, Sukhovei, Galion, Miura by "Auvgust" company of Russian were applied by individually and combination on all fields with rape germination was before and after.
\end{abstract}

Results were given by below. The distribution of weeds were more little $(10 \%=1$ point) in fields of cultivation by chemically and mechanically with planting between were between $20^{\text {th }}$ April to $5^{\text {th }}$ May and were higher medium $(34 \%$ $=3$ point) in field of cultivation by chemically and higher little $(25 \%=2$ point $)$ in field of cultivation by mechanically and lower many $(35 \%=4$ point $)$ in field of stubbles. Additionally, all fields planting time was $10^{\text {th }}$ May. Another experimental results given by distribution of weeds determined were little $(15 \%=2$ point $)$ in field of cultivation by mechanically and medium $(28 \%=3$ point $)$ in field of cultivation by chemically and little many $(50 \%=4$ point $)$ in field of cultivation by, settles field with planting time were $15^{\text {th }}$ May in all fields. Also, average number of seeds of weeds were determine 517.5-922.6 million in 0 to $20 \mathrm{~cm}$ in field's soil by the methods of B.A. Dospekhov et al. The discovered 96 weeds in per square meter of the field and to applied Tornado 50 against weeds, result was stopped of living process of the weeds were $91.6 \%$. But another experimental were discovered 116 weeds for rapeseed with 2-6 real leaves in per square meter of fields and to applied combination both Miura and Gallion against weeds. Results given $95.7 \%$ of weeds were died.
Overall conclusion of all experimental, density of weeds in fields were low/lower on planting by before $10^{\text {th }}$ of May but much more after that planting time. Additionally, planting by after $10^{\text {th }}$ May was to restricting/blocking for rapeseed living in future. This result suggesting to negative influence for rapeseed product quality

Keywords: weed species, soil cultivation, herbicide

\section{INTRODUCTION}

In the "State Food and Agriculture Policy" adopted by the Parliament of Mongolia Resolution No. 29 of 2003, increasing the nomenclature of food, technical, oil and fodder crops, in the soil and climate of the region of Mongolia and produce seeds of their localized varieties. Provides a specific part of domestic plant oil needs, and increases the range and production of strategic and import substitute foods. Rape is the main source of food and technical oils and fodder proteins, and lately it has grown considerably as an economically important to planting crop [8]. To embed production is improving soil fertility, and increasing stabilization of grain yields in connection with Mongolian soil and climatic conditions is important for changing crop rotation structure [1]. Planting of rape for $10-15 \%$ of grain production is an important issue of cultivation. Therefore our country it is urgent to develop proper cultivation of rape and technology of optimal protection against diseases, pests and weeds [5].

\section{MATERIALS AND METHOD IN THE STUDY:}

A total weed species and density of the experimental fields was determined by methods of E.I.Liberschtaine and A. Tulikov ,[4]

1 . The soil samples taken by two type $/ 0-10 \mathrm{~cm}$ and $10-20 \mathrm{~cm} /$ to determine weed seeds in contains soil by method of B.A. Dospekhov,

2. To deem technical result of herbicide, [10]

Azzaya.T, Amarsaikhan.J, Munkhtsetseg.D, Otgonsuren.M, Volume 9 Issue 1, pp 54-59, January 
Volume 9 Issue 1 January 2021

3. To deem harvest by common method,

4. Production experiment field was 3 variant for soil cultivation per 1000 ha, 5 variant for planting time and totaling 15 variants. Tornado 11/ha were used during growth stage, combination of Gallion 0.31/ha+ Miura 0.81/ha herbicides were used during 2-4 leave of rape, dosage of Tornado 1.51/ha 1.81/ha, Sukhovei 1.51/ha, 1.81/ha herbicides used to reduce seed moisture,

Plot experiment are planted mentioned above period, in growing season herbicide was did not used, there are 5 variant of timing difference , 1 plot size was $16 \mathrm{~m}^{2}$ and total was $80 \mathrm{~m}^{2}$.

\section{Climograph 1. Climate features of the years studies}

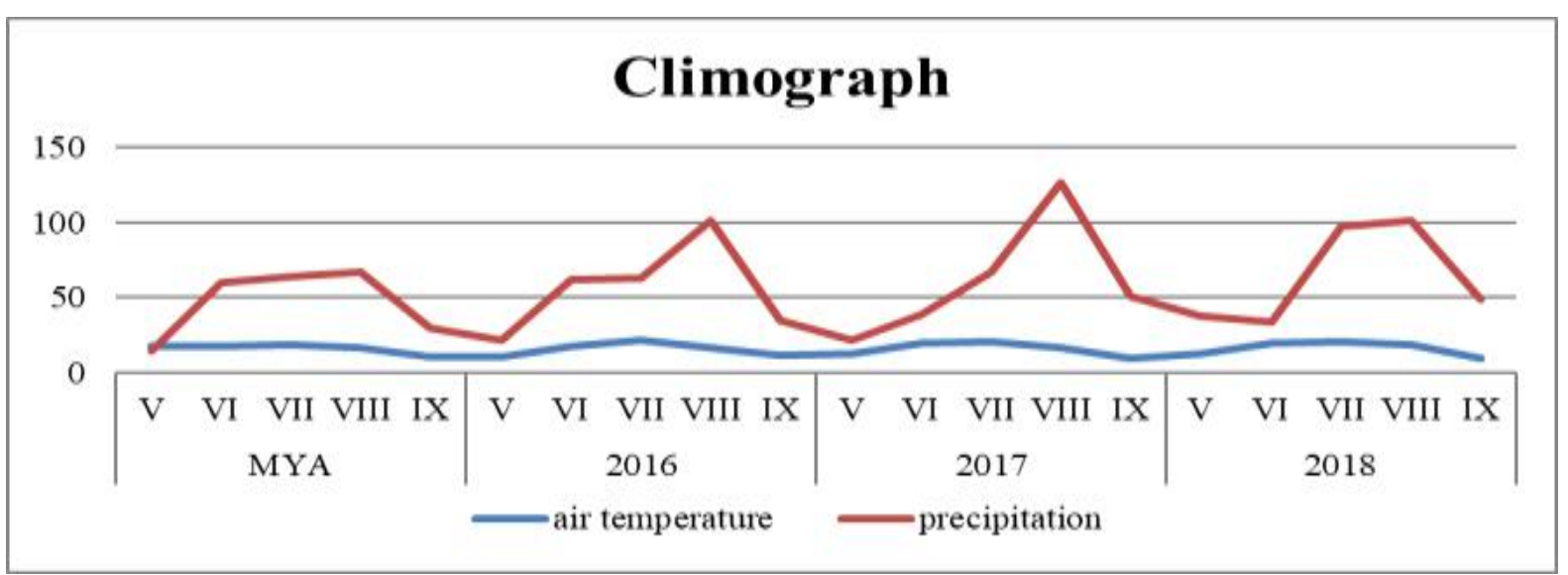

\section{Climate features of the years studies}

Integrating of crop production activities and research results into key of agro climate indicators for the year, Tsagaannuur soum of Selenge province is region of central part of the cultivation area with the moisty chilly summer and cold winters, however the research years was conducted in favorable weather conditions. The average air temperature is $18-20^{\circ} \mathrm{C}$ in July, the coldest being around $20-22^{\circ} \mathrm{C}$ in January. The average annual precipitation is $300-350 \mathrm{~mm}$ and wind speed 1$3 \mathrm{~m} / \mathrm{sec}$. The ground frosts are observed in autumn in August-spring, in late May and early June. Compared MYA (many year avrage) with the 2017-2018 meteorological data for in the 2017 air temperature was $1.10^{\circ} \mathrm{C}$ higher, precipitation was
$70 \mathrm{~mm}$ higher, the number of days above $30^{\circ} \mathrm{C}$ was 21 days, the soil temperature was over $40^{\circ} \mathrm{C}$ day was 96 days, the number of precipitation days was 63 days, in 2018 average air temperature around the MYA, precipitation was $83.2 \mathrm{~mm}$ higher than MYA, number of days above $30 \mathrm{C}$ was 95 days and 60 days with precipitation. The last spring ground frosts were May 28, 2017, May 22, 2018, and the first autumn ground frosts were August 28, 2017 , and September 14, 2018 (climograph 1).

\section{RESULTS OF THE STUDY}

Calculation study result of rape sown different time in cultivating mechanical, chemical fallow and direct straw field of Gatsuurt LLC of Tsagaannuur soum, Selenge province (table 1).

Table 1. Cultivation variant

\begin{tabular}{|c|c|c|c|c|c|c|c|c|c|}
\hline \multirow{2}{*}{ № } & \multirow[t]{2}{*}{ Cultivation variant } & \multicolumn{3}{|l|}{2017} & & & \multicolumn{3}{|l|}{2018} \\
\hline & & \multicolumn{3}{|c|}{ Sown date } & \multicolumn{5}{|c|}{ Sown date } \\
\hline 1 & Mechanical fallow & & & & & & & & \\
\hline 2 & Chemical fallow & IV/20 & $\mathrm{IV} / 25$ & $\mathrm{~V} / 05$ & IV/13 & IV/19 & IV/27 & $\mathrm{V} / 05$ & $\mathrm{~V} / 15$ \\
\hline 3 & Straw & & & & & & & & \\
\hline
\end{tabular}

In 2017-2018, a total of 15 variants, 5 variants of the planting period and 3 variant of soil cultivation were to function in production experiment with a total area of 1000 ha. Before emerging the plant, herbicide of Tornado tested 11/ha and combination of Galion 0.31/ha+Miura $0.81 /$ ha herbicide applied in 2-6 leaves of rape during the growing season. Also, to reduce seed moisture before harvesting, Tornado herbicides were sprayed at 1.51/ha, 1.81/ha, Sukhovei herbicides at $1.51 / \mathrm{ha}$, and $1.81 / \mathrm{ha}$, respectively. During this time, the herbicides was not applied in plot experiment weed during the growing season to chose a convenient time.

Weed research in various soil cultivation variants. 
Volume 9 Issue 1 January 2021

Different types of soil cultivation rape were planted on April 13, 20, 25, May 05, 10, 15. On April 13, the air temperature was $18 \mathrm{C}$ at day, $10 \mathrm{C}$ at night, the soil temperature was $40 \mathrm{C}, 70 \%$ minimum soil moisture content (MSMC) in 0$10 \mathrm{~cm}$ deep. The cultivated rape evenly sprouted around May 9, but in the ground freeze of this day, the emerged seeds were died. Therefore, it was suggested that optimal timing should be compared with MYA. The weed spread on the chemical and mechanical fallow areas planted between April 20 and May 5 was $10 \%$ or less (1 point), and on May 10 weed spread was $34 \%$ or below average (3 points) on chemical fallow, $25 \%$ or lower (2 points) in mechanical fallow, and $35 \%$ or more (4 points) in straw field, weed spread on mechanical fallow planted on May 15 was $15 \%$ or lower (2 points), $28 \%$ or average (3 points) in chemical fallow and $50 \%$ or more (4 points) in the straw field. Therefore spring summer annual and biennial weeds such as Proso millet (Panicum millaceum L), Marijiuna (Cannabis ruderalis Janisch), Leptopyrum fumarioides L, Sieversian wormwood (Artemisia sieversiana Willd) was spreading to dominate in the experinment field.

\section{Research of weed seeds in soil}

The cultivated land contains hundreds of millions of germinative weed seeds and the main reason to determinant of the rate of field pollution is the fact that every year the seeds emerge and the soil weed seed resorces increasing [5]. The weed seeds were sampled to a depth of $0-20 \mathrm{~cm}$ from the soil and identified. 9 weed species belongs to 6 genus and 5 family Amaranth (Amaranthaceae), Goosefoot (Chenopodiaceae), Bindweed (Convolvulaceae), Knotweed (Polygonaceae), Grasses (Poaceae) and Mallows (Malvaceae) weed seeds were detected in soil. Including: Common Mallow (Malva mohileviensis Downer), Goosefoot (Chenopodium album L), Red amaranth (Amaranthus retroflexuse L), Black bindweed (Polygonum convolvulus L), Proso millet (Panicum miliaceum L), Little lovegrass (Eragrostis minor Host) annual 6 weed species seeds were $66.7 \%$, Pink champion (Silene repens Patr), curly dock (Rumex crispus L) and Field bindweed (Convolvulus arvensis L) perennial 3 species weed seeds $33.3 \%$ contained /table $2 /$.

Table 2. Weed seed resource in the soil of rape field (million.pcs)

\begin{tabular}{|c|c|c|c|c|c|}
\hline \multirow[t]{2}{*}{ № } & \multirow[t]{2}{*}{ Variants } & \multirow[t]{2}{*}{$\begin{array}{l}\text { Sample } \\
\text { depth, cm }\end{array}$} & \multicolumn{2}{|c|}{$\begin{array}{l}\text { The number of weed seeds by } \\
\text { biological group (million / pcs) }\end{array}$} & \multirow{2}{*}{$\begin{array}{l}\text { Total number of seed } \\
\text { (million / pcs for } \\
\text { 1/ha) }\end{array}$} \\
\hline & & & $\begin{array}{l}\text { Annual, } \\
\text { Biennial }\end{array}$ & nial & \\
\hline \multirow[t]{2}{*}{1} & Mechanical fallow & $0-10$ & 508.1 & 211.3 & 719.4 \\
\hline & & $10-20$ & 398.3 & 163 & 561.3 \\
\hline \multirow[t]{2}{*}{2} & Chemical fallow & $0-10$ & 678.2 & 196.3 & 874.5 \\
\hline & & $10-20$ & 419.1 & 98.4 & 517.5 \\
\hline \multirow[t]{2}{*}{3} & Straw field & $0-10$ & 721.2 & 201.4 & 922.6 \\
\hline & & $10-20$ & 496.0 & 179.7 & 675.7 \\
\hline
\end{tabular}

Straw field contains 922.6 million $/ \mathrm{pcs} 0$ $10 \mathrm{~cm}$ layer of soil, 675.7 million $/ \mathrm{pcs} 10-20 \mathrm{~cm}$ layer of soil and it is higher than other variants.

\section{Weed spread and density of experiment field.}

In 2017,19 weed species belongs to 16 genus, 12 family were identified in the rape field of Tsaganuur soum in Selenge province, 10 species are $50 \%$ of annual, 2 species are $7.7 \%$ of biennial, 7 species are $42.3 \%$ of perennial weeds, in 2018 , 16 weed species belongs to 15 genus, 15 family were recorded, 8 species are $53.3 \%$ of which were annual, 1 species are $6.6 \%$ of biennial, 6 species are $40 \%$ of perennial weeds, respectively. $(1,2-$ diagram).

\section{Weed spread density of field}

Diagram 1.
Diagram 2.

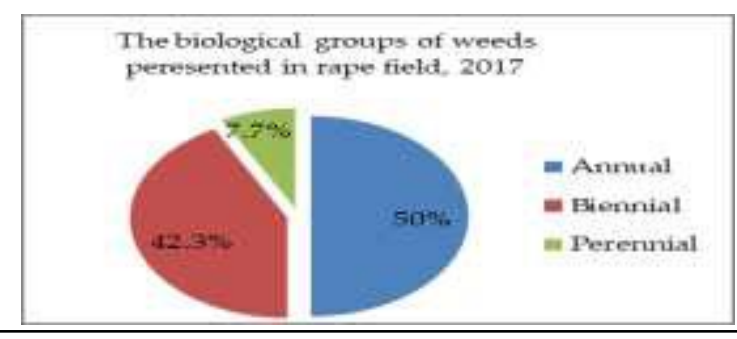


Volume 9 Issue 1 January 2021

The weeds spread in the area of the experiment are classified by species: Proso millet (Panicum millaceum L.), Little lovegrass (Eragrostis minor Host), Red amaranth (Amaranthus retroflexus L.), Black bindweed (Polygonum convolvulus L), Goosefoot (Chenopodium album L.), slender Russian thistle (S.collina Pall), (Leptopyrum Fumarioides L.), Tackweed (Tribulus terrestris L.), Marijuana (Cannabis ruderalis Janisch), Common mallow (Malva mohileviensis Downer), Stephen's stork's bill (Erodium stephanianum Willd.), Siberian geranium (Geranium sibiricum L.), Sieversian wormwood (Artemisia sieversiana Willd), Quack grass (Agropyron repens (L.)

Beauw), Meadow cranesbill (Geranium pretense L), Forked leaf (Potentilla bifurca L.), Field bindweed (Convolvulus arvensis Ln.) Common dandelion (Taraxacum officinale Wigg.), British yellowhead (Inula britannica L) there were spreading 19 weed species [9].

\section{Herbicide result on rape field:}

When the weeds sprouted on the rapeseed field from seedling to germination, sprayed Tornado herbicide at a dose of $11 /$ ha and it is eliminating the spring-summer weeds and emerging were evenly growing. Before sown emerge there were counted 96 weeds per $1 \mathrm{~m}^{2}$. During the growing season in the rape field with 26 leaves, weeds total number counted of 116 per $1 \mathrm{~m}^{2}$ the results were calculated by against broadleaf weeds spraying mixture of Gallion herbicide at 0.31 /ha and Miura herbicide at a dose of $0.81 /$ ha, respectively.

Table 3. Technical effectiveness of herbicides, \% (rape field)

\begin{tabular}{|c|c|c|c|c|c|c|}
\hline \multirow{3}{*}{ № } & \multirow{3}{*}{ Variants } & \multirow{3}{*}{$\begin{array}{c}\text { Dosage of } \\
\text { herbicide, (l/ha) }\end{array}$} & \multicolumn{4}{|c|}{ Decrease of weeds } \\
\hline & & & \multicolumn{2}{|c|}{ Spraying } & \multicolumn{2}{|c|}{ Decrease } \\
\hline & & & $\begin{array}{l}\text { Before } \\
/ \mathrm{pcs} / \mathrm{m}^{2} /\end{array}$ & $\begin{array}{c}\text { After } \\
/ \mathrm{pcs} / \mathrm{m}^{2} /\end{array}$ & $\begin{array}{l}\text { Number, } \\
/ \mathrm{pcs} / \mathrm{m}^{2} /\end{array}$ & $\begin{array}{l}\text { Percenta } \\
\text { ge }\end{array}$ \\
\hline 1 & Tornado & 11/ha & 96 & 7 & 88 & 91.6 \\
\hline 2 & Gallion+Miura & $0.31 / h a+0.81 / h a$ & 116 & 5 & 111 & 95.7 \\
\hline
\end{tabular}

The Tornado herbicide sprayed at the production field showed technical results of $91.6 \%$, the combination of Gallion 0.31/ha + Miura 0.81/ha herbicide $95.7 \%$. (table 3). In herbicide-free variants of the timing diffrent field, rape plants were predominantly grown before May 10, but after May 10 cultivated field the weed density was huge, to strangle and rape growth was limited, the

Table 4. Weed density of depending on planting time

\begin{tabular}{clcccc}
\hline \multicolumn{7}{c}{ Wo } & \multicolumn{1}{c}{ Weed species } & IV/25 & V/05 & V/10 & V/15 \\
\hline 1 & Goosefoot & 10 & 15 & 15 & 15 \\
\hline 2 & Black bindweed & 8 & 20 & 20 & 20 \\
\hline 3 & Barnyard millet & - & - & - & 4 \\
\hline 4 & Green foxtail & - & - & 20 & 5 \\
\hline 5 & Red amaranth & 3 & 13 & 6 & 6 \\
\hline 6 & Common mallow & - & - & 2 & 5 \\
\hline 7 & Knotgrass & 21 & 51 & 63 & 75 \\
\hline
\end{tabular}

As can be seen from the table, on May 15, in the sown area, summer and autumn annual Green foxtail and Barnyard millet grew 75 pieces per $1 \mathrm{~m} 2$, which is slowed down the growth of rape and affects nocuous the crop.

Reducing rape seed moisture: In $65 \%$ of the total area before harvest the total field seed moisture content at $24-28 \%, 7-10$ days after pods and the seeds became moldy on their stems, which had a detrimental effect on the quality of the product. Therefore, taking into data the climate condition and soil moisture of the present year, it is necessary to correctly cultivate and carry out plant protection measures in expedient (table 4). 
Table 5. Herbicide effect on rape yield

\begin{tabular}{|c|c|c|c|c|c|c|}
\hline Plantation time & Variants & 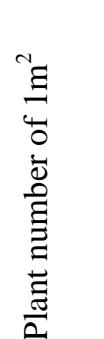 & 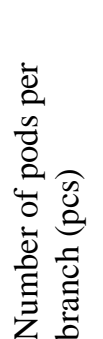 & 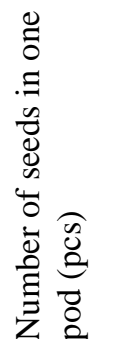 & 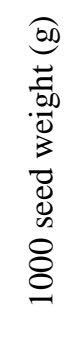 & 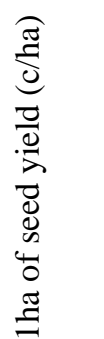 \\
\hline \multicolumn{7}{|c|}{2017} \\
\hline \multirow[t]{3}{*}{$\mathrm{IV} / 20$} & Straw & 60 & 33 & 24 & 3.11 & 14.8 \\
\hline & Fallow & 72 & 26 & 26 & 3.43 & 16.7 \\
\hline & Chemical fallow & 80 & 23 & 23 & 3.73 & 15.8 \\
\hline \multirow[t]{3}{*}{ IV/25 } & Straw & 80 & 30 & 22 & 3.01 & 15.7 \\
\hline & Fallow & 70 & 32 & 21 & 4.07 & 19.1 \\
\hline & Chemical fallow & 60 & 24 & 22 & 3.1 & 9.8 \\
\hline \multirow[t]{2}{*}{$\mathrm{V} / 5$} & Straw & 78 & 30 & 24 & 3 & 16.8 \\
\hline & Chemical fallow & 80 & 30 & 22 & 3.06 & 16.2 \\
\hline & & 2018 & & & & \\
\hline \multirow[t]{3}{*}{ IV/27 } & Straw & 58 & 30 & 31 & 3.1 & 16.7 \\
\hline & Fallow & 68 & 38 & 28 & 3.4 & 16.5 \\
\hline & Chemical fallow & 60 & 35.3 & 33.3 & 3.2 & 22.6 \\
\hline \multirow[t]{3}{*}{$\mathrm{V} / 5$} & Straw & 51 & 31 & 28.6 & 3 & 14 \\
\hline & Fallow & 56 & 33 & 26.3 & 3.4 & 16.5 \\
\hline & Chemical fallow & 56 & 30 & 28 & 3.1 & 14.6 \\
\hline \multirow[t]{3}{*}{$\mathrm{V} / 11$} & Straw & 58 & 7 & 26 & 3.2 & 13.9 \\
\hline & Fallow & 80 & 25 & 22 & 3.2 & 14.1 \\
\hline & Chemical fallow & 58 & 27 & 29 & 3.2 & 14.5 \\
\hline \multirow[t]{3}{*}{$\mathrm{V} / 15$} & Straw & 38 & 33.6 & 19.4 & 3.08 & 7.6 \\
\hline & Fallow & & 25 & 22 & 3.01 & 10.1 \\
\hline & Chemical fallow & 44 & 28 & 24 & 3.2 & 9.5 \\
\hline
\end{tabular}

As for soil cultivation, planted rapeseed on mechanical fallow from IV / 25 to May 11 with an average of 2 years yield was $16.1 \mathrm{~h} / \mathrm{ha}$, which was best of all other variants. Therefore, mechanical fallow resulted in to set crop conditions on April 25 and 27, when the air temperature was $16{ }^{\circ} \mathrm{C}$ at night, $-30{ }^{\circ} \mathrm{C}$, the soil temperature was 5 ${ }^{\circ} \mathrm{C}$ and the MSMC was $75 \%$ at $0-10 \mathrm{~cm}$ depth.

Biochemical indicators of crop:

Table 6. Biochemical indicators of planting diffrent timing rape

\begin{tabular}{|c|c|c|c|c|c|c|}
\hline \multirow[t]{2}{*}{ № } & \multirow[t]{2}{*}{ Time } & Sown type & $\begin{array}{c}\text { Moisture, } \\
\%\end{array}$ & Butyric, \% & $\begin{array}{c}\text { Capacitance } \\
\text { weight, } \mathrm{g} / \mathrm{l}\end{array}$ & Protein, $\%$ \\
\hline & & $\begin{array}{c}\text { MNS } \\
4791: 2005\end{array}$ & $\begin{array}{l}\text { Not more } \\
\text { than } 10 \%\end{array}$ & $\begin{array}{c}\text { Not less } \\
\text { than } 40 \%\end{array}$ & $\begin{array}{c}\text { Not less than } \\
600 \mathrm{~g} / 1\end{array}$ & $\begin{array}{c}\text { Not less than } \\
18 \%\end{array}$ \\
\hline 1 & IV/20 & \multirow{6}{*}{ Rape } & 6.4 & 42.7 & 690 & 27.1 \\
\hline 2 & IV/25 & & 6.4 & 44.5 & 664 & 25.4 \\
\hline 3 & $\mathrm{~V} / 5$ & & 5.1 & 47.6 & 651 & 20.4 \\
\hline 4 & IV/27 & & 5.5 & 41.7 & 650 & 26.4 \\
\hline 5 & $\mathrm{~V} / 11$ & & 7.3 & 43.7 & 684 & 26.4 \\
\hline 6 & $\mathrm{~V} / 15$ & & 8 & 45.8 & 604 & 22.4 \\
\hline
\end{tabular}

The biochemical of the rape was analyzed by the laboratory of the Gatsuurt LLC, the amount of moisture, butyric and protein was within the standard level (Table 6).

\section{DISCUSSION}

S.A.Tastenov has the most important thing is planting dates in the technology of rapeseed cultivation, it is recommended to sow later in the 
Volume 9 Issue 1 January 2021

regions of Kazakhstan and Siberia, and when sowing before May 10, the yield was $84.9 \mathrm{c} / \mathrm{ha}$, then on $91.4 \mathrm{c} /$ ha on 10 and $161.2 \mathrm{c}$ on 20 yield of green mass. The researcher also explained that when planted late, moisture growing environment comfortable and it is less to receive damage from the pest.

And V. Medvedev from 1974 to 1976 , according to a study of the Ussur Experiment Station in the Krasnoyarsk Territory, it is beneficial when cultivating rape for seed, at the end of April or early May, between rows $15 \mathrm{~cm}$ and $10-13 \mathrm{~kg}$ per 1 ha (3.5 million pieces) in depth of $1-3 \mathrm{~cm}$.

Rape is relatively little studied in our country, mainly Orgodol KH in the Central region from 1985 to 1987, and Munkhjargal $\mathrm{O}$ in the Dornod region from 1991 to 1998. According to Orgodol H's research, May 5-15 was the best time to plant rapeseed in the usual $15 \mathrm{~cm}$ row, yielding up to $10 \mathrm{c} /$ ha of seed, which was a good idea to grow in a simple row.

The time variants of the above researchers was consistent with the fact that in our study chemical, mechanical fallow and straw fields rape planting from April 20 through May 10 , there was a 10-28\% lower spread of weeds [13].

Darkhan PGRFA's researcher Bayarsukh N in 2001-2004, gene fund irrigation field in the central farming region of river Kharaa, Ramrod herbicide at a dose of $7 \mathrm{~kg} / \mathrm{ha}$ against a weeds white bud on the soil was sprayed one day before the spring cultivating and technical result was $84.6 \%$. Fuzialad super herbicide sprayed during growing season when the segmented grass annual and perennial weeds become $10-15 \mathrm{~cm}$, technical results was $21 /$ ha dose $78.3 \%$, 31/ha dose $75.2 \%$, 41/ha dose version $80.2 \%$ and yield was increased 2.4-5.5 c/ha. Using chemical method is effective before and after weeding of rape crops/and increasing yields were in line with our research [7].

Researchers Enkhbold N, Azzaya T, Batchimeg T, and Batsaikhan Central area's Modify Survey in 2017, Gatsuurt LLC's wheat and rape non irrigated fields weeds were determined, such as the, Proso millet, Black bindweed, Red amaranth, Goosefoot, Siberian geranium, Sieversian wormwood, Field bindweed, Monkswort. Field weed level was 2-3 point, Proso millet 10, Black bindweed $4 \mathrm{p}$, Monkswort 4 pcs were counted on $1 \mathrm{~m}^{2}$ [11].

\section{CONCLUSION}

1. Cultivation of rape in the area of chemical, mechanical fallow and straw field from April 20 to May 10, weed spread was low by $10-28 \%$.

2. When seed moisture $24-28 \%$ total of $65 \%$ field during harvest, all variant of Tornado 1.5 1/ha, 1.81/ha, Sukhovei 1.51/ha, 1.81/ha doses sprayed to reduce the seed moisture, either version was effective, the moisture was reduced to $7.9-8.3 \%$ after 7-10 days. Plantation of rapeseed in mechanical fallow on IV/25 yield was $19.1 \mathrm{c} /$ ha which is higher than other variants.

\section{REFERENCES}

1. Ayurzana B, Munkhjargal O., 1995, UB Technology of cultivating rape in the conditions of Dornod with non-irrigation

2. Bek TV, 1989 " World collection and prospects for seed production ", No. 5, pages 55-56.

3. Gruzev G.S. "Actual problems of weed control" Liberstein. I.I., Tulikov.A. M. "Modern methods for the study and mapping of weediness" p. 54-58

4. Mijiddorj. "Features of Weed Management Technology in Mongolia" p 69-70, 2002

5. Munkhjargal O., "Technology of Cultivation of Oil crops under Irrigation in the Dornod"

6. Munkhjargal O., "Oil Crops,” 2007, UB

7. Munkhjargal O., Doctoral thesis, "Cultivation of sunflower, rape for oil in the Dornod Mongolian agricultural zone", 2000.

8. Munkhjargal O., "Technology of cultivating rape" 2013, UB

9. Tserenbaljid.G. "Colorful Album of the Mongolian weeds " 2002

10. "Integrated Technology - Canada " Handbook 200, p 90-94

11. Work Report of the Ministry of Agriculture, "Study of plant diseases, weeds, pests, rodents distribution and pest control " in the Central region /Selenge aimag / arable land, 2017.

12. Orgodol $\mathrm{KH}$, "Some issues of spring rape agrotechnics under the conditions of the Central Labor Protection Ministry of the MPR" 